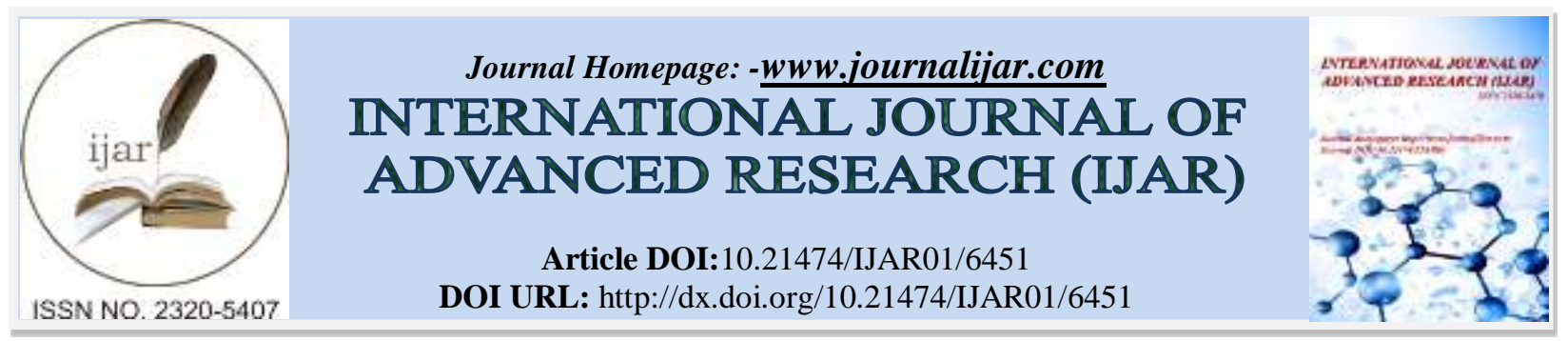

RESEARCH ARTICLE

\title{
GEOGRAPHICAL ANALYSIS OF ONDO STATE GUBERNATORIAL ELECTION RESULTS OF 2012 AND 2016.
}

Richard Babajide Adeleke.

Department of Geography, University of Ibadan.

\section{Manuscript Info}

Manuscript History

Received: 05 December 2017

Final Accepted: 07 January 2018

Published: February 2018

Keywords:-

Election, GIS, Spatial Autocorrelation,

Ondo State, Nigeria

\begin{abstract}
Space is one of the key drivers of election results and the few studies on the influence of space on election results in Nigeria reported a mere spatial distribution without giving an insight into their spatial clustering. Using Global and Local Moran's I geospatial techniques, the study found a significant positive spatial autocorrelation and clustering of votes in 2012 election for the candidates of Peoples Democratic Party in Ilaje, Irele and Ese-Odo local government areas while that of Action Congress of Nigeria was in Owo and Akoko Southwest. In 2016 election, that of All Progressives Congress was in Owo and Ondo East. However, there was a significant negative spatial autocorrelation and clustering of votes for the candidates of Labour Party in Akure North and Alliance for Democracy in Ese-Odo and Ilaje in 2012 election. On the whole, the pattern of votes cast for the victorious party in 2016 election was found to be more regionally concentrated when compared to 2012. The study concluded that a lot still has to be done with regard to voters' education.

Copy Right, IJAR, 2018,. All rights reserved.
\end{abstract}

\section{Introduction:-}

In democratic societies, election is a major means through which electorate choose their representative. It is a means of political expression which involves the translation of the wishes of the people into political decisions (Verma, 2015). Since it is a normal practice in most democratic states for candidates to campaign prior to election, the campaigns are usually targeted at the factors that appeal to the sentiments of the electorate; such as their locality, religion, ethnicity among others (Lawal, 2017).

The geographical traits of a territory have been identified as potential drivers of electorate decision (Verma, 2015). As a result, people with similar beliefs and values tend to live close to one another, and vote along the same lines in elections (Johnston et al., 2004). Over the years, the role of space in determining election results has attracted the interest of researchers, even though there are few actual studies on this in Nigeria. In a review of few past studies carried out by Thurston (2015), Bello (2015) and Oji et al., (2014), they adopted a largely descriptive approach and correlational statistical analysis which gave a mere spatial distribution of election results without giving an insight into their spatial clustering. It can then be argued, that such a situation only creates a mirage on the influence of space in determining election results.

In recent times, geospatial techniques aided by Geographical Information Systems have been used to analyze and understand the distribution of phenomena. This could be attributed to their ability to shed more light on unusual 
spatial cluster (Djukpen, 2010). Geospatial technique has been used in understanding election results in most developed countries of the world. Using spatial econometric model, Burnet and Lacombe (2012) analysed the polarization of 2004 presidential election in United States of America between John Kerry and George Bush, in which spatial association was found to have influenced the election results.

Also, with the aid of spatial econometric model, Guirreiro and Caleiro (2003) examined the link between voters' ideology and election results for the two main parties in Portugal; geographical location was found to be a predictor of the election outcome. Based on the use of spatial regression, Wu et al., (2006) showed that there were strong neighbourhood influences on the formation of national identity which often affects election outcome. Using exploratory spatial analysis and spatial econometric modeling, Amara and El Lagha (2014) argued that election results in Tunisian's 2011 National Constituent Assembly Election were spatially dependent. Spatial factor was also found to determine Taiwan's 2004 presidential elections at both the village and township levels with the aid of spatial regression model (Lay et al., 2007).

In Nigeria, the application of geospatial technique to the understanding of election result is limited. It is in this regard that this study adopted Global and Local Moran's I geospatial techniques to understand the role of space in determining election results in Ondo State, Nigeria.

Ondo State is one of the states in Nigeria with diverse political parties and where the rivalry among the major political parties, that is; Peoples Democratic Party, Labour Party, All Progressives Congress and Alliance for Democracy is intense. These parties have ruled Ondo State at one time or the other. The choice of 2012 and 2016 gubernatorial elections is to have a better understanding of the dynamic nature of election results in Ondo State. This is because the 2012 and 2016 elections brought into power two different political parties. This study intends to contribute to geospatial techniques studies in Nigeria. Also, to help policy makers have a better understanding of the political orientation of the people in order to come up with appropriate form of political enlightenment. Thus, the objective of this study is to carry out a geographical analysis of election results in Ondo State gubernatorial elections of 2012 and 2016. To achieve this, the analysis was carried out at the local government level of the state with the aid of geospatial technique. The following research questions were addressed in order to achieve the central objective of the study:

1. What is the spatial pattern of votes cast for the gubernatorial candidates of major political parties?

2. Are they clustered or randomly distributed over space?

3. Does geographical location really determine voting pattern?

\section{Study Area:-}

Ondo State, created on the $3^{\text {rd }}$ of February, 1976 is located in Southwestern part of Nigeria around Latitude $5^{\circ} 45^{\prime} \mathrm{N}$ to $7^{\circ} 45^{\prime} \mathrm{N}$ of the Equator and Longitude $4^{\circ} 30^{\prime} \mathrm{E}$ to $6^{\circ} 0^{\prime} \mathrm{E}$ of the Greenwich. It has its capital in Akure. It is bounded by Kogi and Ekiti States to the North; Ogun and Osun States to the West; Edo, Delta State and by the Atlantic Ocean to the South (Owombo et al., 2014). The state is characterized by high temperature and rainfall as a result of its location in the rainforest belt. Thus, the inhabitants are largely farmers cultivating both cash and food crops such as cocoa, palm, rubber, maize, kolanut, yam and cassava. The state is made up of eighteen local government areas. The urban local government areas include; Akoko Northwest, Akoko Northeast, Akoko Southeast, Akoko Southwest, Akure North, Akure South, Ondo West, Ondo East and Owo, while the rural local government areas include; Ose, Ifedore, Ile-Oluji/Okeigbo, Idanre, Odigbo, Okitipupa, Irele, Eseodo and Ilaje. Election in Ondo State, just like in any part of the country is conducted every four years, of which the recent election was conducted in 2016. The state has been governed by four different political parties, that is; Alliance for Democracy, Peoples Democratic Party, Labour party and All Progressives Congress between 1999 and 2016. This is a reflection of the multi-party system and intense rivalry among the major political parties. Despite the aforementioned, the state has experienced smooth political transition from one democratic administration to another. In the new democratic dispensation (1999 till date), Adebayo Adefarati, Olusegun Agagu, Olusegun Mimiko have ruled the state at one time or the other with Rotimi Akeredolu as the incumbent governor. 


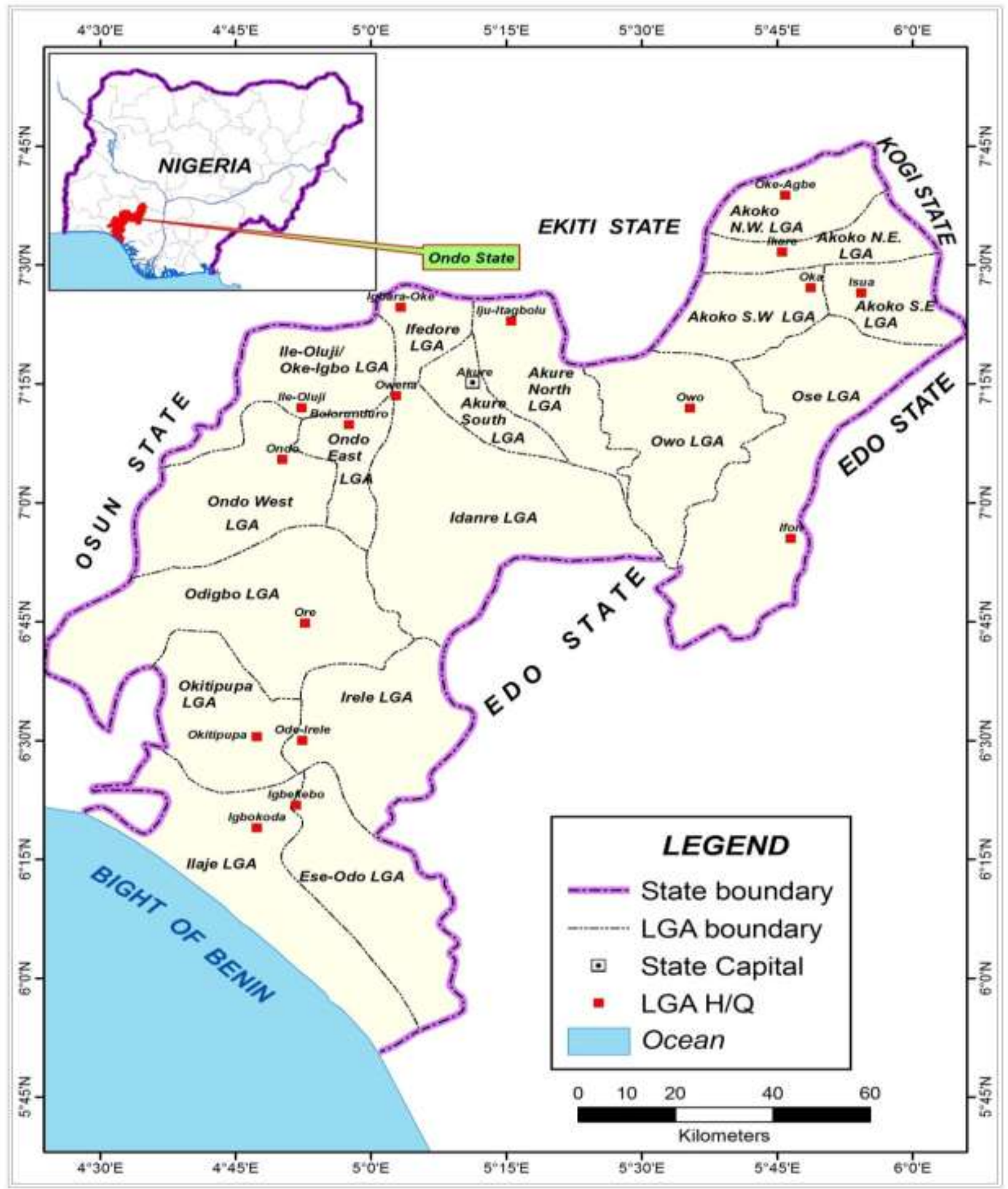

Fig1:- Study Area

\section{Methodology:-}

Secondary data was used mainly for this study. Data on votes cast for the gubernatorial candidates of major political parties in each local government area in 2012 and 2016 elections were obtained from the Independent National Electoral Commission. The major political parties that won at least a local government during the 2012 and 2016 gubernatorial elections were chosen for this study. In 2012 election, Action Congress of Nigeria, Labour Party and 
Peoples Democratic Party were the major political parties that contested and won at least a local government during the election. Similar yardstick was used in choosing All Progressives Congress, Peoples Democratic Party and Alliance for Democracy in 2016 gubernatorial election. To help demonstrate how the spatial patterns of votes cast for the gubernatorial candidates of major political parties vary across space, the study mapped the results in all the local government areas using ArcGIS software, version 10. After mapping the election results, the degree of spatial autocorrelation was measured using Global and Local Moran's I.

The data were subjected to Global Moran's I analysis in order to measure the degree of spatial clustering of votes cast for the gubernatorial candidates of major political parties in the study area. This is with the view of determining the pattern exhibited, be it clustered or randomness. A Moran's I index value near +1.0 indicates clustering. It is also an indication of positive autocorrelation, as phenomena of interest with like values are contiguous over space. While an index near -1.0 indicates dispersion. This is a situation of negative autocorrelation, which means that there are observations with dissimilar values. Although the Global Moran's I is a good measure of spatial autocorrelation, its limitation lies on the fact that it does not show the actual location of the clustering. As a result, the Local Moran's I was adopted to make up for this short coming. The Local Moran's I measure whether the votes cast in each local government for the gubernatorial candidates of major political parties is closer to the values of its neighbours. For the purpose of this study, votes cast for the gubernatorial candidates were expressed in percentages and rated as high or low votes cast. That is;

$\mathrm{CV} / \mathrm{TVC} \times 100$

Where CV is for candidate's votes and TVC for total votes cast for the candidates

Hence, five types of clustering patterns were anticipated; High-High which indicates the clustering of high voting pattern (positive spatial autocorrelation), High-Low which indicates that high voting pattern is adjacent low ones (negative spatial autocorrelation), Low-Low which indicates that there is the clustering of low voting pattern (positive spatial autocorrelation), Low-High indicating low voting pattern is adjacent high ones (negative spatial autocorrelation) and not significant value which means no spatial autocorrelation.

\section{Results and Discussion:-}

Spatial Distribution of Votes Cast for Major Political Parties in 2012 and 2016 Elections:-

Figures 2 to 7 show the spatial distribution of votes cast for the major political parties in 2012 and 2016 elections. As illustrated by the map, there was a noticeable geographic variation in the votes won by the parties. In 2012 election, the votes cast for Peoples Democratic Party was generally low (12.1 to 27.2\%). This was reported in Akure North, Owo, Ose, Akoko Southeast and Akoko Northeast, Ondo West, Ile-Oluji, Ondo East, Idanre, Akure South and Ifedore, while average vote (27.3 to $42.2 \%$ ) was observed in Odigbo, Irele, Akoko Southwest, Akoko Northwest and Ese-odo. However, Ilaje and Okitipupa reported high votes cast (42.3 to 57.3\%). The pattern of votes cast for Labour Party also indicated a significant proportion of low votes (15.6 to 35.3\%) in Odigbo, Idanre, Ondo East, IleOluji, Ifedore, Akure South, Owo, Ose, Akoko Southwest, Akoko Southwest, Akoko Northeast and Akoko Northwest. On the other hand, average vote (35.4 to 55.1\%) was identified in Okitipupa, Irele and Ese-Odo while high vote (55.2 to $74.8 \%$ ) was observed in Ondo West. Unlike the pattern of votes won by Peoples Democratic Party and Labour Party, the pattern of votes cast for Action Congress of Nigeria indicates a significant proportion of both low and average votes. Low vote (13.1 to $24.1 \%$ ) was observed in Ilaje, Ese-Odo, Irele, Okitipupa, Idanre, Ondo West, Ondo East and Akure South while there was average vote (24.2 to 35.2\%) in Ile-Oluji, Ifedore, Akure North, Ose, Akoko South East, Akoko Northeast and Akoko Northwest. In addition, there was high vote won (35.3 to $46.2 \%$ ) in Odigbo, Owo and Akoko Southwest. From the foregoing, all the parties won low votes in Ondo East, Idanre and Akure South. 


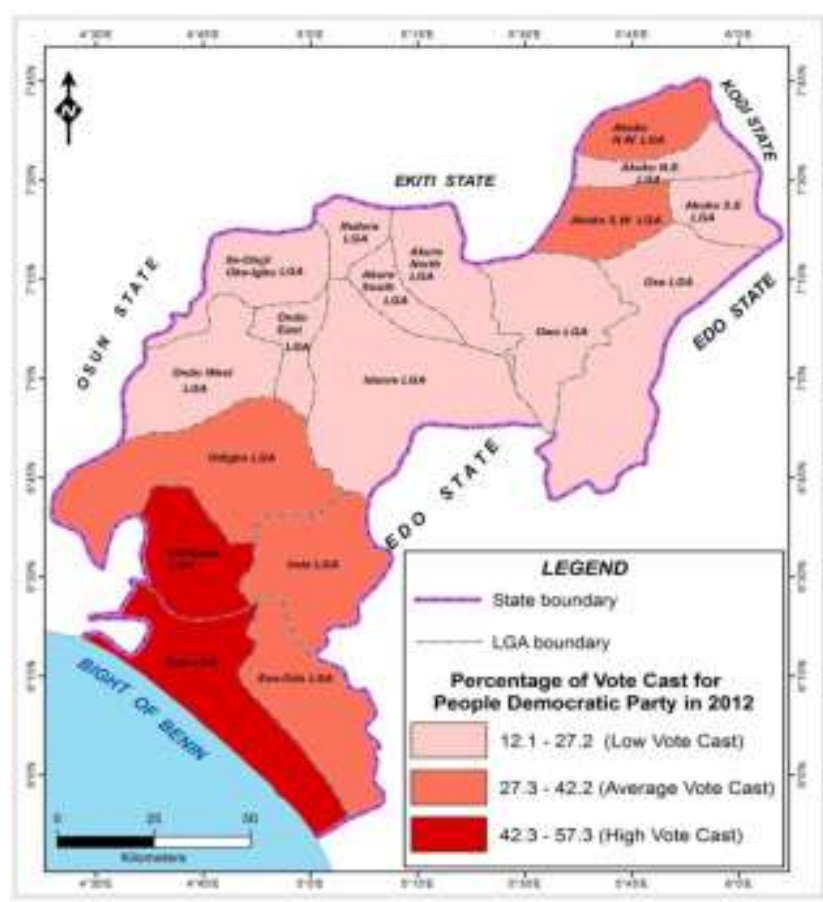

Fig 2:- Votes cast for PDP in 2012

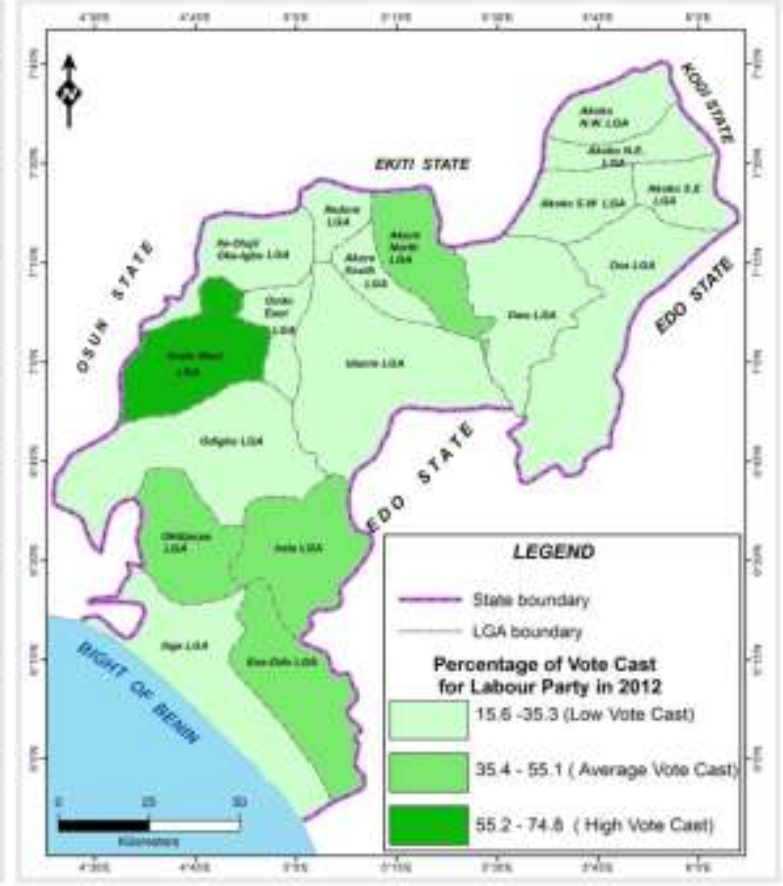

Fig 3:- Votes cast for LP in 2012

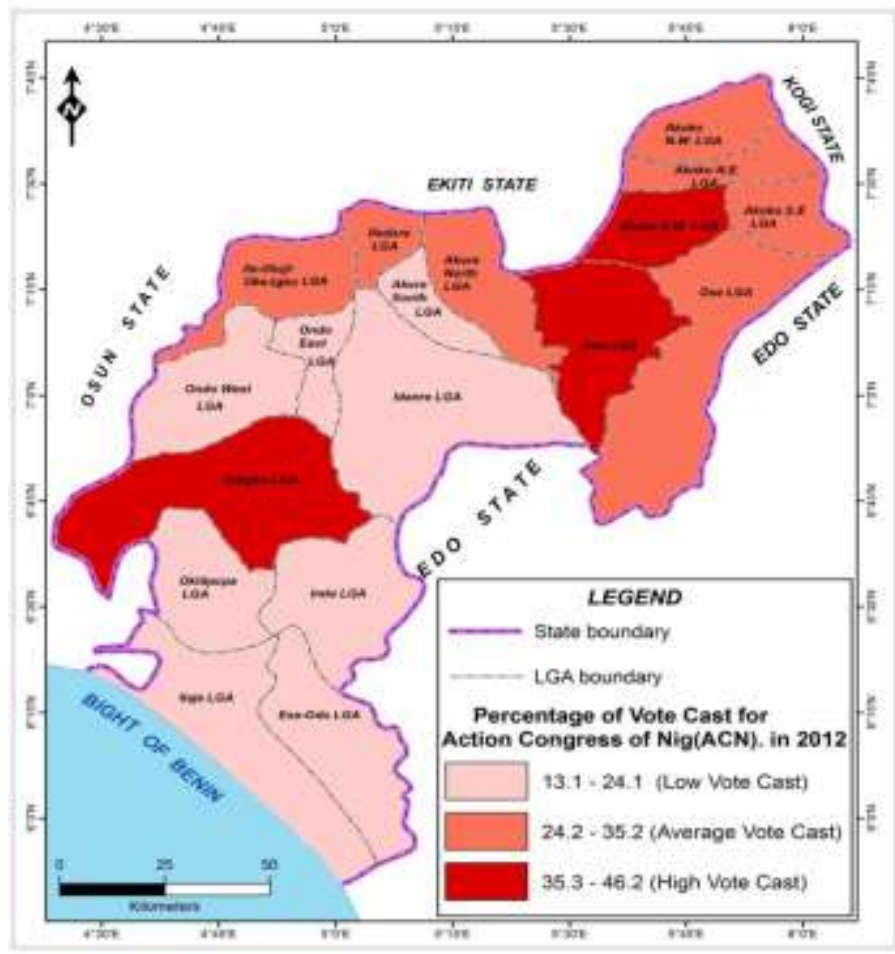

Fig 4:- Votes cast for ACN in 2012

In 2016 election, average vote (40.3 to 61.6\%) accounted for a substantial percentage of votes cast for All Progressives Congress in Ese-Odo, Irele, Odigbo, Idanre, Ile-Oluji, Ifedore, Akure South, Akure North, Ose, Akoko Southwest, Akoko Southeast, Akoko Northeast and Akoko Northwest. There was, however, low vote (18.7 to $40.2 \%$ ) in Ondo West, Ondo East, Okitipupa and Ilaje while high vote (61.7 to $83.1 \%$ ) was noticed in Owo. The pattern of votes cast for Peoples Democratic Party was found to be almost similar to that of All Progressives 
Congress as a significant proportion of average votes were won (23.7 to 36.5\%). This was reported in Ese-Odo, Irele, Odigbo, Idanre, Ondo East, Ile-Oluji, Ifedore, Akure North, Ose, Akoko Southeast, Akoko Northeast and Akoko Northwest. Low vote (10.7 to 23.6\%) was won in Akoko Southwest, Owo, Ilaje and Okitipupa while there was high vote (36.6 to 49.4\%) in Akure South and Ondo West. In contrast to the pattern of votes cast for All Progressives Congress and Peoples Democratic Party, there was a substantial amount of low votes cast (6.2 to $25.8 \%$ ) for Alliance for Democracy in Ese-Odo, Odigbo, Ondo West, Idanre, Ondo East, Ile-Oluji, Ifedore, Akure South, Akure North, Owo, Ose, Akoko Southwest, Akoko Southeast, Akoko Northeast and Akoko Northwest. Elsewhere, average vote ( 25.9 to $45.5 \%$ ) was observed in Okitipupa and Irele while there was high vote (45.6 to $65.1 \%$ ) in Ilaje. The spatial pattern of votes cast for the parties show that all the parties won average votes in Irele. From a comparative perspective, none of the parties was able to win high votes in the elections, as they were all confined to winning low votes.

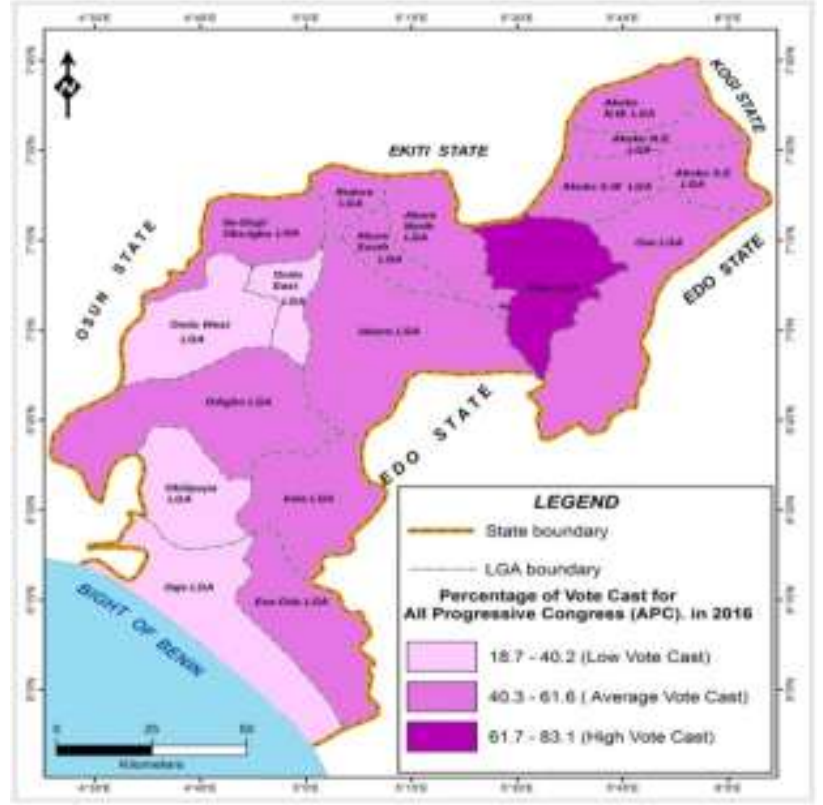

Fig 5:- Votes cast for APC in 2016

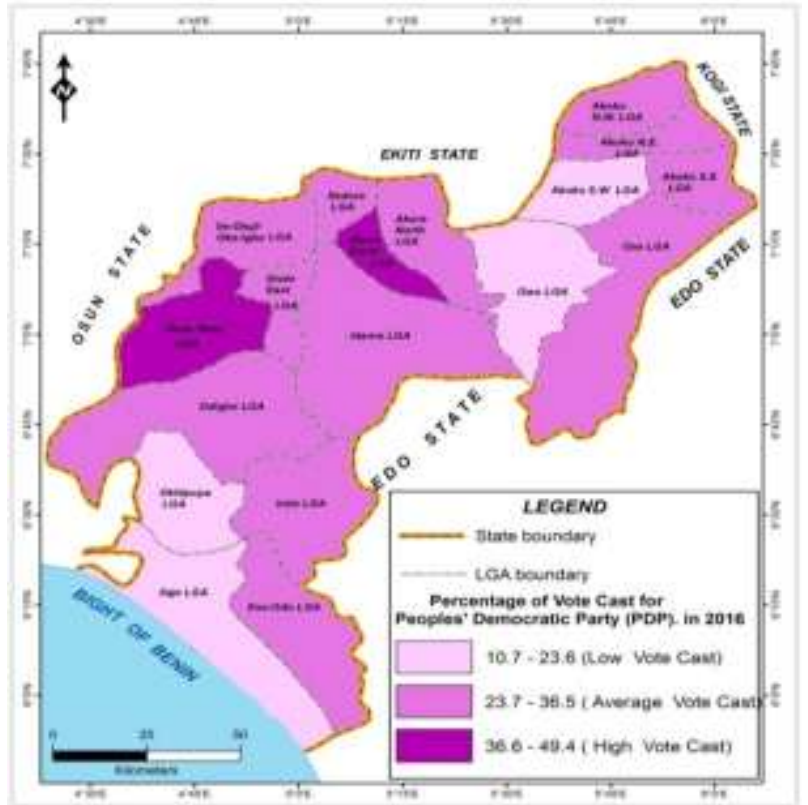

Fig 6:- Votes cast for PDP in 2016

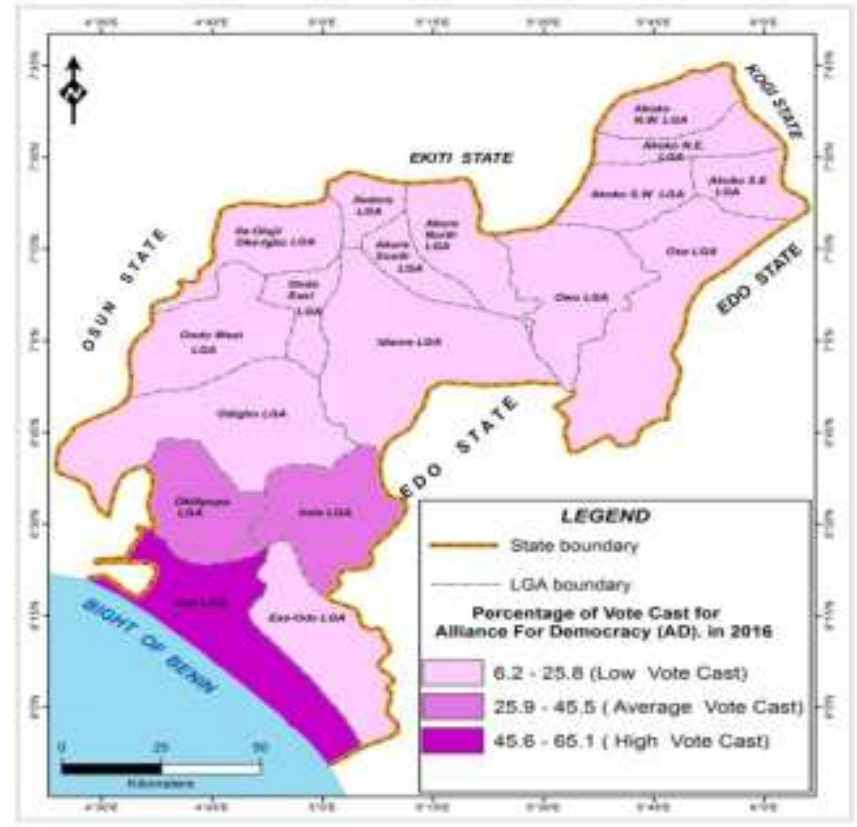

Fig 7:-Votes cast for AD in 2016 


\section{Spatial Clustering of Votes Cast for Major Political Parties:-}

The local pattern of association for votes cast for the major political parties in the elections are shown in Figures 8 to 13 and Table 1. In 2012 election, there was a positive spatial autocorrelation (similarity in voting pattern) with high votes cluster in Ilaje, Irele and Ese-Odo local government areas for the candidate of Peoples Democratic Party. These three local government areas based on their location are contiguous. Based on personal observation, the presence of Igbokoda major road linking the south local government areas; specifically Ilaje, Irele and Ese-Odo to Edo State is expected to create frequent contact among the people of the various local government areas through which they can reach a consensus on the candidate to vote for. The election result was also found to be positively auto correlated with high votes cluster for the candidate of Action Congress of Nigeria in Owo and Akoko Southwest. This also, could be attributed to the contiguity of the local government areas. Ehinmowo and Ibitoye (2010) argued that one of the key factors encouraging spatial interaction between Owo and Akoko Southwest local government areas is the presence of Ika market located at the border of Owo and Akoko Southwest. Based on the geographical location of Akoko Southwest in the tropics, farming has become the major occupation of the people; hence, both food and cash crops such as cocoa, kola nut, yam, cassava, among others are sold at cheaper prices. Thus, the market serves as converging point for hundreds of buyers and sellers from Owo and Akoko Southwest which has created an avenue for interaction. The similarity in voting pattern observed from the findings of this study due to geographical contiguity, confirms the assertion of Johnston et al., (2004) cited in Amara and El Lahga (2014) that those who live together talk together, those who vote together act like each other. Unlike the positive spatial autocorrelation in votes observed for Peoples Democratic Party and Action Congress of Nigeria, a negative spatial autocorrelation (high-low cluster of votes) was exhibited for Labour Party in Akure North. In other words, while the candidate of Labour Party won high votes in Akure North, low votes were won in the neighbouring local government areas, that is; Owo, Akure South, Ifedore and Idanre. This is an indication that the election result was dissimilar between Akure North and the surrounding local government areas.

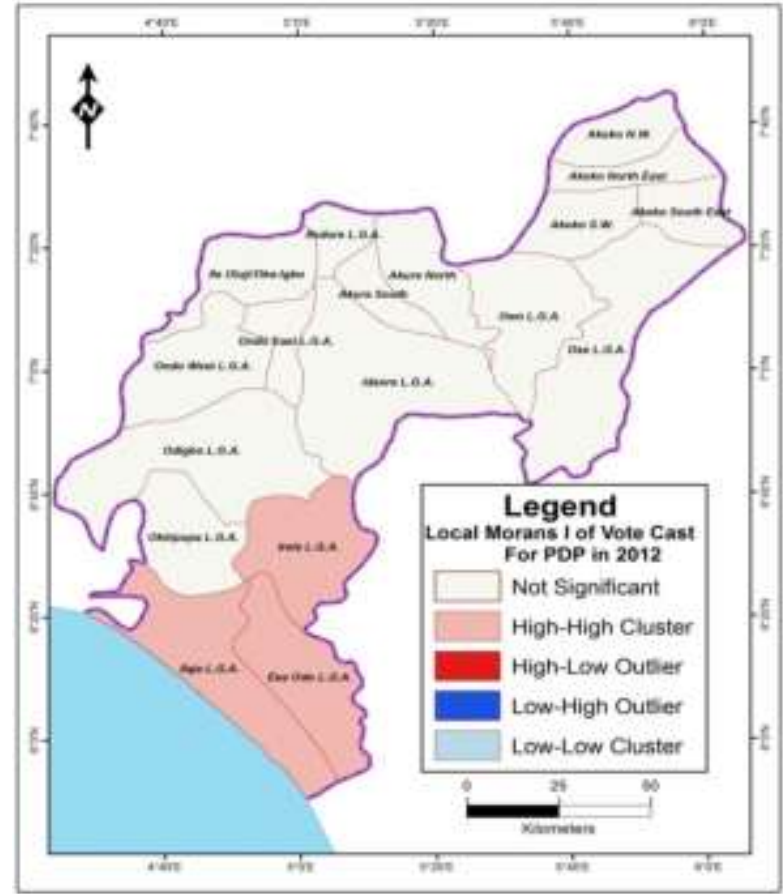

Fig 8:- PDP Local Moran’s I in 2012

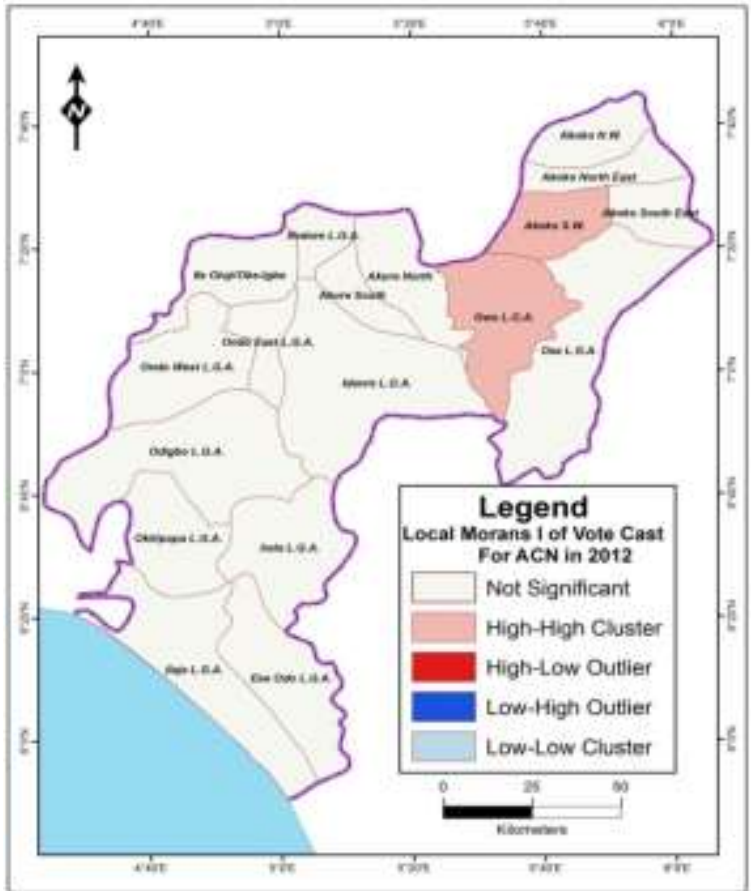

Fig 9:- ACN Local Moran’s I in 2012 


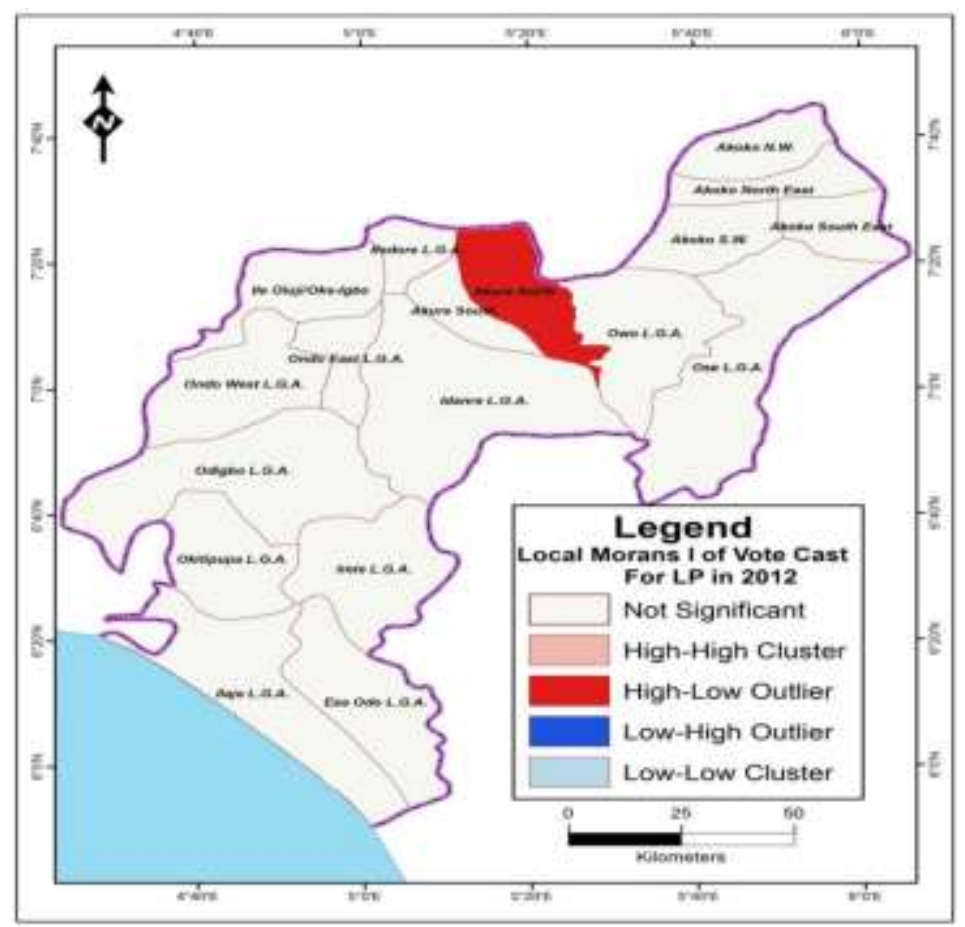

Fig 10:- LP Local Moran's I in 2012

Furthermore, in 2016 election, a positive spatial autocorrelation was found in the votes cast for the candidate of All Progressives Congress. There was an isolated cluster of high vote in Owo. This indicates that high votes were won in the contiguous local government areas. This may not be surprising, as Owo is the local government area of origin of the candidate. As a result, he is expected to win majority of votes due to home advantage. There was, however, an isolated cluster of low votes cast for All Progressives Congress in Ondo East. This connotes that while the candidate won low votes in Ondo East, low votes were also won in the neighboring local government areas. The low votes won in Ondo East could be attributed to its nearness to Ondo West, the local government of origin of the then incumbent governor, Olusegun Mimiko of Peoples Democratic Party. All other things being equal, Olusegun Mimiko was expected to secure the votes of Ondo East for Peoples Democratic Party. In addition, there was a negative spatial autocorrelation (High-Low cluster) of votes cast for the candidate of Alliance for Democracy in Ilaje and Ese-Odo. Thus, while the candidate of Alliance for Democracy won high votes in Ilaje, low votes were won in Ese Odo. Home advantage was also found to be one of the reasons for the clustering of high votes cast for the candidate of Alliance for Democracy; Olusola Oke who hails from Ilaje. On the other hand, the clustering of low votes in Ese-Odo may be due to the fact that Ese-Odo supported her home candidate, Agboola Ajayi, a running mate to the candidate of All Progressives Congress. The cases of negative spatial autocorrelation in election results from the foregoing discussion is an indication that geographical contiguity does not necessarily guarantee similarity in the voting behaviour of the electorate, even in a situation of frequent interaction among the people. 


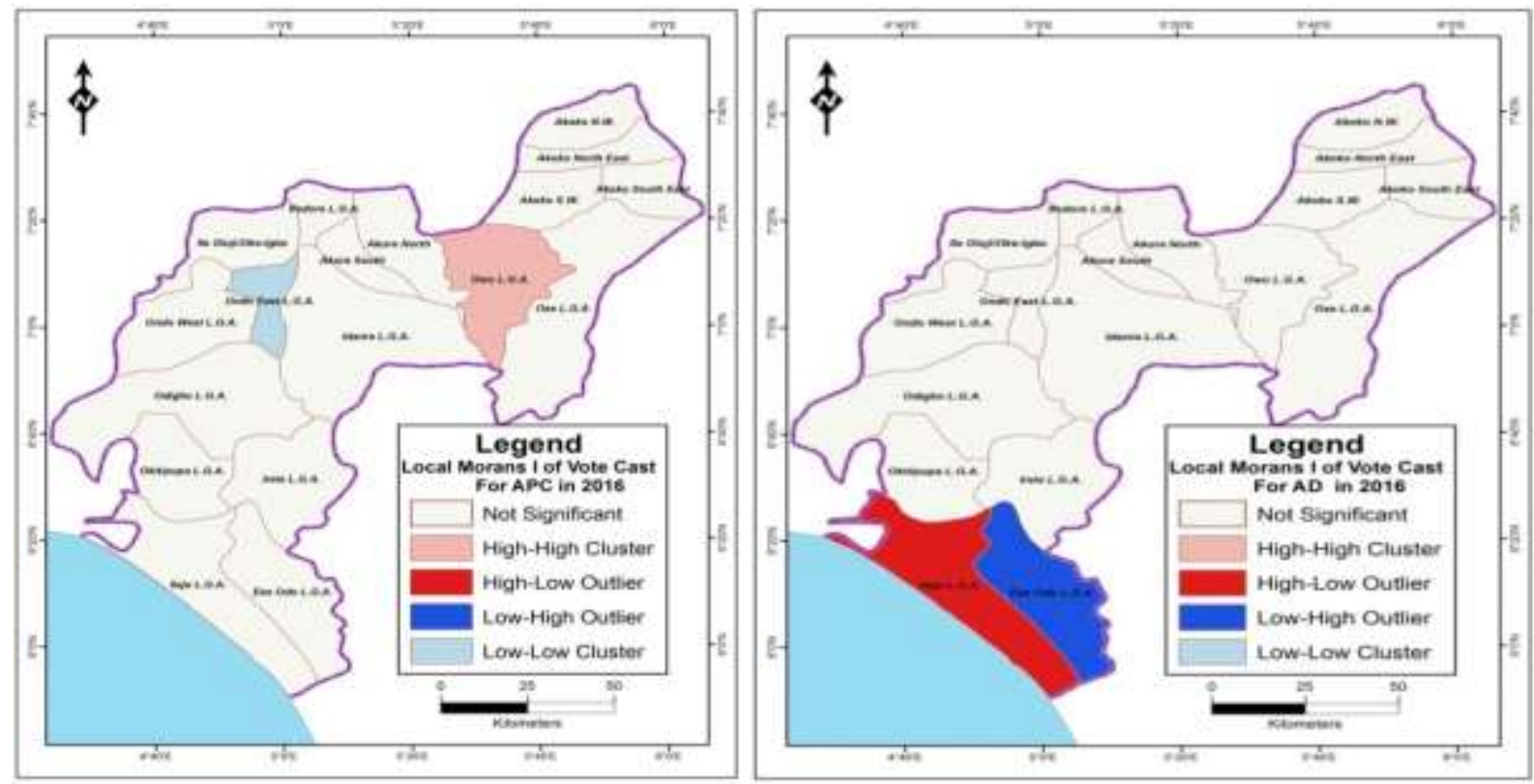

Fig 11:- APC Local Moran's I in $2016 \quad$ Fig 12:- AD Local Moran's I in 2016

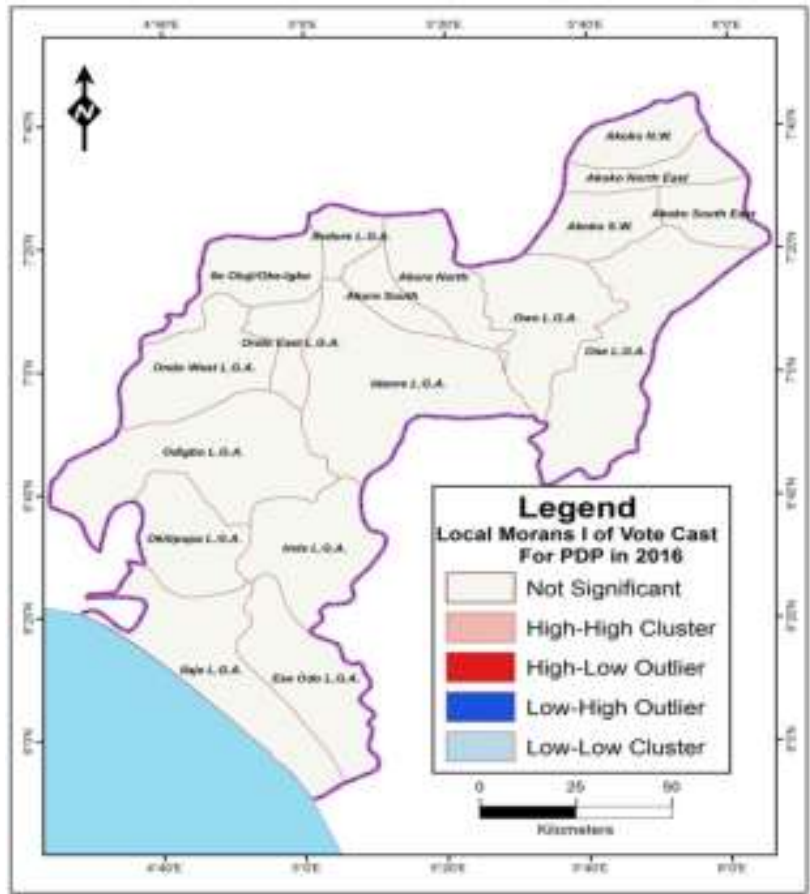

Fig 13:- PDP Local Moran's I in 2016 
Table 1:- Local Moran's I values for votes cast

\begin{tabular}{|l|l|l|l|l|l|l|}
\hline $\begin{array}{l}\text { Election } \\
\text { Year }\end{array}$ & $\begin{array}{l}\text { Moran's } \\
\text { Index }\end{array}$ & Z-Score & P-Value & Remark & Party & $\begin{array}{l}\text { Local } \\
\text { government } \\
\text { area }\end{array}$ \\
\hline 2012 & 0.000204 & 2.491110 & 0.052734 & HH & PDP & Ilaje \\
\hline 2012 & 0.000124 & 2.263452 & 0.054567 & HH & PDP & Eseodo \\
\hline 2012 & 0.000633 & 2.687932 & 0.055411 & HH & PDP & Irele \\
\hline 2012 & 0.000118 & 2.205105 & 0.057446 & HH & ACN & Owo \\
\hline 2012 & 0.000157 & 2.205105 & 0.057446 & HH & ACN & $\begin{array}{l}\text { Akoko } \\
\text { Southwest }\end{array}$ \\
\hline 2012 & -0.000201 & -2.491110 & 0.052734 & HL & LP & Akure North \\
\hline 2016 & 0.000135 & 2.619653 & 0.058801 & HH & APC & Owo \\
\hline 2016 & 0.000117 & 1.970174 & 0.058818 & LL & APC & Ondo East \\
\hline 2016 & -0.000081 & -2.340655 & 0.059249 & HL & AD & Ilaje \\
\hline 2016 & -0.000081 & -2.340655 & 0.059249 & LH & AD & Eseodo \\
\hline 2016 & Nil & Nil & Nil & Nil & PDP & Nil \\
\hline
\end{tabular}

Note:- Significant at 0.05 significance level

Note:- HL=High-Low

LL=Low-Low

LH=Low=High

On the whole, in the election, the pattern of votes cast for the candidates of Action Congress of Nigeria (in 2012), Peoples Democratic Party (in 2012) and All Progressives Congress (in 2016) was clustered (see table 2). In other words, these candidates won elections in local government areas that are contiguous rather than those that are dispersed. Thus, largest votes for these candidates came from local government areas that share contiguous boundaries, and based on this, it can be reasonably concluded that their influence was limited to few localities and not the entire state. It can also be argued, that an inverse relationship exists between distance and votes won by the candidates. Hence, votes won declined with increasing distance from their local governments of origin. This was, however, not the case for the candidate of Labour Party in 2012 election, Peoples Democratic Party and Alliance for Democracy in 2016 election, as the pattern of votes won was randomly distributed over space (see table 2). This suggests that votes won increased with increasing distance from the local government of origin of the candidates. Therefore, the votes won were not regionally concentrated. As a result, the 2012 and 2016 elections produced two different candidates as winners with varying levels of acceptability among populace in Ondo State. While geographical contiguity largely determined the victory of All Progressives Congress in 2016 election, this was not the case for the victory of the candidate of Labour Party in 2012 election. It is then logical to conclude that neighbourhood effect determined election result in 2016 election while other factors accounted for the results in 2016.

Table 2:- Global Moran's I for Votes Cast

\begin{tabular}{|l|l|l|l|l|l|}
\hline Election Year & Moran's Index & Z-Score & P-Value & Remark & Party \\
\hline 2012 & 0.039358 & 1.730621 & 0.083519 & Clustered & ACN \\
\hline 2012 & -0.025247 & 0.579788 & 0.052058 & Random & LP \\
\hline 2012 & 0.017974 & 2.181668 & 0.029134 & Clustered & PDP \\
\hline 2016 & -0.024838 & 0.540877 & 0.038593 & Random & AD \\
\hline 2016 & 0.033433 & 1.959653 & 0.050036 & Clustered & APC \\
\hline 2016 & -0.018233 & 0.332992 & 0.052534 & Random & PDP \\
\hline
\end{tabular}

Source: Author

\section{Conclusion:-}

This study has been able to shed more light on the influence of space on election results through the aid of geospatial technique. Based on the findings of this study, the influence of space in determining election result is a two way thing. While geographical contiguity can bring about a similarity in voting pattern, it can also bring about dissimilarity. These were reflected in 2012 and 2016 election results. In 2016, geographical contiguity was largely responsible for the victory of All Progressives Congress candidate while this was not the case for the victory of Labour Party candidate in 2012 election. The shift towards regional induced votes is not a good sign for the nascent 
democracy of the state, as this may lead to a weak democratic structure. Hence, the electorate should look beyond the geographical location of candidates contesting election when voting, even though, the influence of space in shaping electorate decisions cannot be totally ruled out. This then draws attention to the need for an intensive voter education in the State.

\section{References:-}

1. Amara, M. and El Lagha, A. (2014). Tunisian Constituent Assembly Elections: How Does Spatial Proximity Matter? Springer Science Business Media Dordrecht. DOI 10.1007/s11135-014-0137

2. Bello, S.K. (2015). Political and Electoral Violence in Nigeria: Mapping, Evolution and Patterns (pp 9-19). Nigeria Working Paper Series.

3. Burnet, W, and Lacombe, D.J (2012). Accounting for Spatial Autocorrelation in the 2004 Presidential Popular Vote: A Reassessment of the Evidence. The Review of Regional Studies, 42, 75-79.

4. Djukpen, R. (2010). Mapping the HIV/AIDS epidemic in Nigeria using Exploratory Spatial Data Analysis. Geojournal 75(2):1-15. DOI: 10.1007/s10708-010-9350-1

5. Ehinmowo, A.A \& Ibitoye, A.O (2010). Periodic Market, a Common Market Feature in Akoko Soutwest. Journal of Geography and Regional Planning. Vol 3(12) pp.361-364

6. Gurreiro, G, and Caleiro, A. (2003). Explaining the Election Results in Portugal: A Spatial Econometrics Point of View. European Regional Science Association.

7. Independent National Electoral Commission. (Online) Available: http://www.inecnigeria.org (May, 12, 2017).

8. Johnston, R.J., Jones, K., Sarker, R., Propper, C., Burgess, S. \& Bolster, A. (2004). Party Support and the Neighborhood Effect: Spatial Polarisation of the British Electorate, 1991-2001. Political Geography 23 (4): pp. 367-402.

9. Lawal, O. (2017). Geographical Pattern and Structure of the 2011 and 2015 Nigeria Presidential Elections. African Geographical Review, DOI: 10.1080/19376812.2017

10. Lay, J.G., Yap, K.H, and Chang, C.C (2007). Spatial Perspectives and Analysis on Voting Behaviour. A Case Study of the 2004 Taiwan Presidential Election. Xiuanju Yanju Journal of Electoral Studies. 14, 33-60.

11. Oji, R.O., Sunday, O.V., \& Agata, F.I. (2014). Voting Pattern in Imo State Governorship Election of 2011. Global Advanced Research Journal of History, Political Science and International Relations Vol 3 (2) pp (017029).

12. Owombo, P.T., Koledoye, G.F., Ogunjimi, S.I., Akinola, A.A. and Deji, O.F (2014). Farmer's Adaptation to Climate Change in Ondo State, Nigeria: A Gender Analysis. Journal of Geography and Regional Planning. Vol. 7(2), pp. 30-35.

13. Thurston, A. (2015). Background to Nigeria's 2015 Elections (pp 10-14). Centre for Strategic and International Studies.

14. Verma, W. (2015). Setting the Rules of the Game. The Choice of Electoral Systems in Advanced Democracies. American Political Geography Review 93:609(624)

15. Wu, C.E., Lin, T.M, and Lee, F.Y (2006). Neighborhood Influence on the Formation of National Identitity in Taiwan. Political Research Quarterly, 59, 35-46. 